Indonesian Journal of Nutrition and Dietetics Vol. 6, No. 2, 2018: 64-69
Available online at: http://ejournal.almaata.ac.id/index.php/IJND DOI : http://dx.doi.org/10.21927/ijnd.2018.6(2).64-69

\title{
Porang flour with keji beling maceration reduced total cholesterol levels in diabetic rats male wistar rats
}

\author{
Eva Nurinda', Hamam $\mathrm{Hadi}^{2}$, Anggun Putri Lestari² \\ ${ }^{1}$ Departement of Pharmacy, Faculty of Health Science, Universitas Alma Ata, \\ Jalan Brawijaya no.99 Tamantirto Yogyakarta \\ ${ }^{2}$ Departement of Nutritions Science, Faculty of Health Science, Universitas Alma Ata, \\ Jalan Brawijaya no.99 Tamantirto Yogyakarta \\ Email: evanurinda@gmail.com
}

\begin{abstract}
ABSTRAK
Latar belakang: Hiperkolesterolemia merupakan komplikasi pada DM yang ditandai dengan meningkatnya kadar kolesterol total. Prevalensi hiperkolesterolemia pada DM mencapai 20\%-90\%. Beberapa penelitian menyebutkan bahwa glukomanan dalam tepung porang yang merupakan serat dapat menurunkan kadar kolesterol.

Tujuan: Mengetahui efek tepung porang (Amorphophallus oncophyllus) dengan maserasi keji beling (Strobilanthes crispa) terhadap kadar kolesterol total pada tikus wistar jantan (Rattus norvegicus) DM tipe 2. Metode: Penelitian ini bersifat eksperimen murni dengan rancangan pre post with control group design. Subjek penelitian adalah 35 ekor tikus yang dibagi dalam 5 kelompok yaitu kontrol negatif, kontrol positif, pembanding, tepung porang murni, dan porang dengan ekstrak Strobilanthes crispa. Serum darah semua tikus diambil setelah 14 hari perlakuan untuk diukur kadar kolesterol total. Kemudian hasil dianalisis menggunakan ANOVA yang dilanjutkan dengan uji beda nyata (Duncan).

Hasil : Pemberian tepung porang ekstrak Strobilanthes crispa dapat menurunkan kadar kolesterol total lebih baik sebesar $28,76 \%$ dibandingkan tepung porang murni yang dapat menurunkan kadar kolesterol total sebesar 15,35\% $(p=0,05)$. Kadar air feses hari ke-1 dan hari ke-14 tidak berbeda nyata pada semua kelompok.

Kesimpulan : Dari hasil penelitian dapat disimpulkan bahwa pemberian tepung porang dengan maserasi ekstrak Strobilanthes crispa dapat menurunkan kadar kolesterol total lebih baik dibandingkan tepung porang murni.
\end{abstract}

Kata Kunci: diabetes melitus, keji beling, Strobilanthes crispa, kolesterol total, tepung porang,

\begin{abstract}
Background: Hypercholesterolemia is a complication in DM characterized by increased of total cholesterol levels. Prevalence of hypercholesterolemia in DM reached $20 \%-90 \%$. Several studies stated that glucomannan in porang flour which is a fiber may lower cholesterol levels.

Objective: To understand the effect of porang flour (Amorphophallus oncophyllus) with keji beling (Strobilanthes crispa) maceration of total cholesterol levels in male wistar rats (Rattus norvegicus) DM type 2.

Methods: This study used on experimental with pre post with control group design. The subjects were 35 rats divided into 5 groups: negative control, positive control, comparison, pure porang intervention, and porang flour with Strobilanthes crispa extract. The blood serum of all rats was taken after 14 days of treatment to measure total cholesterol levels. Then the results were analyzed using ANOVA followed by real difference test (Duncan).

Results: Porang flour with Strobilanthes crispa maceration decreased total cholesterol level by $28.76 \%$ compared to pure porang flour which only reduced total cholesterol level equal to $15,35 \%(p=0,05)$.

Conclusions: From the results of this study it can be concluded that the provision porang flour with Strobilanthes crispa maceration can lower total cholesterol level better than pure porang flour.
\end{abstract}

KEYWORDS: diabetes mellitus, keji beling, Strobilanthes crispa, total cholesterol, porang flour 


\section{INTRODUCTION}

Type 2 diabetes mellitus is a complex endocrine and metabolic disorder. The interaction between several genetic and environmental factors results in a heterogeneous and progressive disorder with variable degrees of insulin resistance and pancreatic $\beta$-cell dysfunction (1). Prevalence rates of type 2 diabetes increased from $3.21 \%$ (3.19; $3.22)$ in 2004 to $5.26 \%(5.24 ; 5.29)$ in 2014 . The incidence and prevalence of type 2 diabetes in patients aged 16 to 34 years increased over time. (2). Indonesia is the seventh country ranked with diabetes mellitus (DM) patients (8.5 million) after China, India and the United States, Brazil, Russia, Mexico. World health organized (WHO) also predicts DM patients in Indonesia may increase to 21.3 million patients by 2030 . This will make Indonesia ranks fourth after the United States, China, and India in diabetes prevalence (3). Diabetics have a tendency to develop hypercholesterolemia in which fat is converted into energy because the sugar in the blood cannot be processed into energy. As a result cholesterol is formed in the fat metabolism chain has increased. The prevalence of hypercholesterolemia in DM is very high at $20-90 \%$ (4).

The porang tuber (Amorphophallus oncophyllus) belongs to the Araceae family which contains high fiber (glucomannan) and can be used in industry, pharmacy and food (5). Glucomannan also can be used as a therapy for insulin resistance patients because it can fix lipid profile. The most widely consumed by the community is glucomannan. Use of tuber or porang flour is still a polemic because of the content of Ca-oxalate. One of the efforts to remove Ca-oxalate in porang flour is by immersion of porang flour with Strobilanthes crispa leaf extract. According to previous research that the Strobilanthes crispa leaf can dissolve the cumulation of Ca-oxalate, so that the Strobilanthes crispa leaf can be used to reduce kidney stone because of Ca-oxalate commulation (6). Other Study said that the consumption of keji beling that followed in porang after the soaking process may also have the advantage effect in the body (7).

Application of porang flour to lower cholesterol level is unknown by the public and also there is no scientific evidence about the efficacy of porang flour in lowering cholesterol levels. This led the authors to study the effects of porang flour with Strobilanthes crispa maceration to lowering total cholesterol levels in wistar rats (Rattus norvegius) with DM type 2. We are expected to study the effect of porang flour Strobilanthes crispa maceration of total cholesterol levels in male wistar rats (Rattus norvegicus) with type 2 DM.

\section{MATERIALS AND METHODS}

This research was part of research that coordinated by ACHEAF (Alma Ata Center For Healthy Life and Food). Thus, there are similarities of methods performed by other researchers, but the difference lies in the dependent variable of blood glucose, HDL and LDL, and triglycerides. This research was experimental research with pre post-control group design. The research was conducted at the Laboratory of Food and Nutrition Study Center (PSPG) Universitas Gadjah Mada (UGM) from June to July 2017. This research was approved with ethical clearance from Universitas Alma Ata with number: KE/AA/V/172/EC/2017. We used 35 male white rats (Rattus norvegicus) aged 7-8 weeks and mean body weight of 150 grams. Porang flour (Amorphophallus oncophyllus) was obtained from Madiun, East Java province. Porang flour was soaked by Strobilanthes crispa extract and ethanol $96 \%$ for 1 day with 2 times rinsing using $96 \%$ ethanol. Soaking devices include containers and covers, filters, and dryers. The instruments that used are cannula, measuring glass, microhaematocrit, Eppendorf tube, manual scales, cholesterol kit, centrifugation, spectrophotometer, and vortex.

Thirty five rats were devided into 5 treatment groups: negative control group was a group that not induced with streptozotocin, positive control group was a group that induced with streptozotocin, comparison group was a group with $0.09 \mathrm{mg}$ glibenclamide, pure porang flour intervention group was a group with with pure porang flour dosage 1.1 $\mathrm{g}$, and porang flour with Strobilanthes crispa extract was an intervention group with $1.1 \mathrm{~g}$. porang flour 


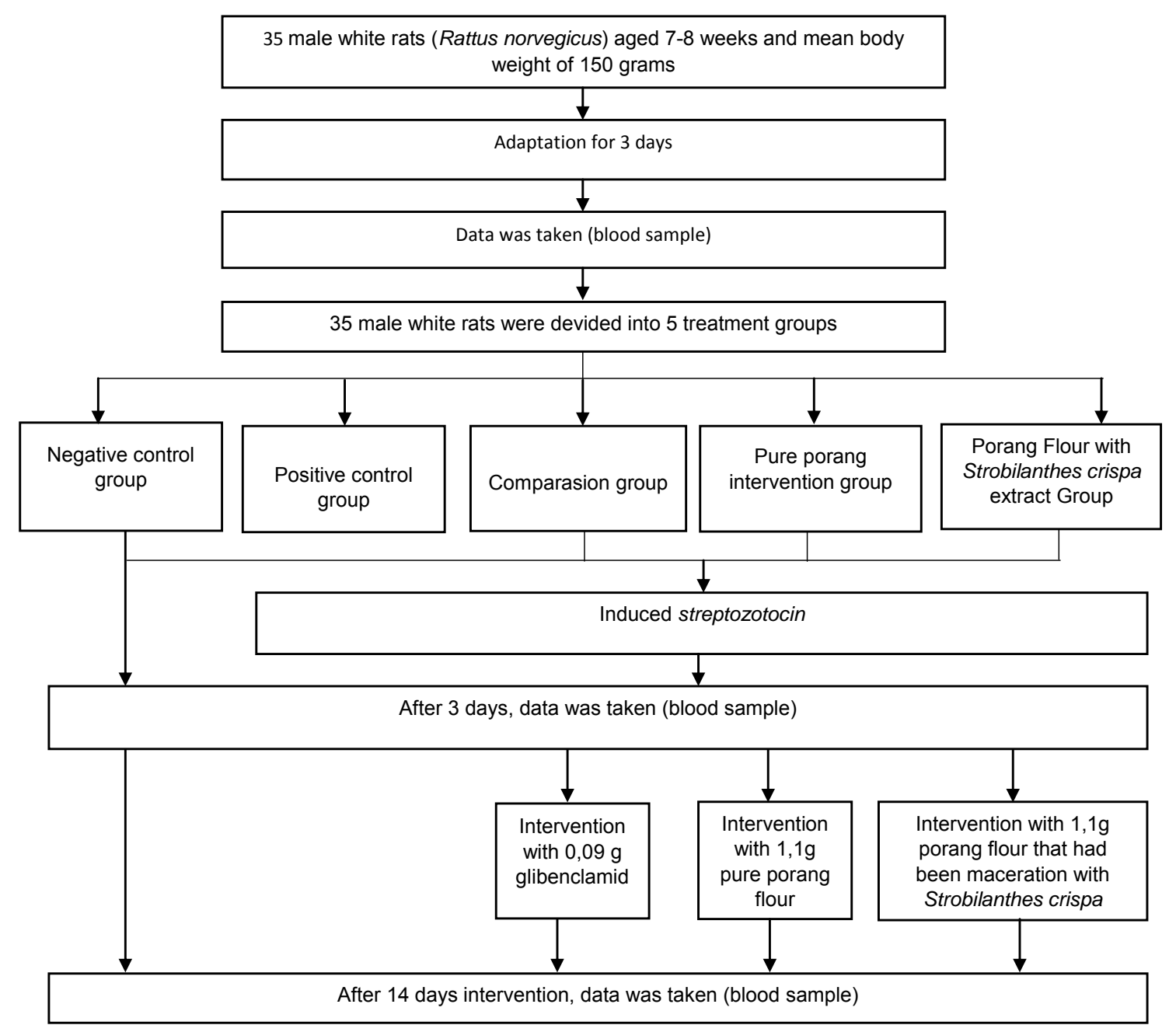

Picture 1. Experiment Flow Chart

that had been maceration with Strobilanthes crispa extract. Intervention was administered by mixing porang flour into standard AIN 93 feed. Treatment was performed for 14 days (2 weeks). Blood rats sampling was take 3 times, the first was take after 3 days adaptation (as control), second was take after 3 days induction of streptozotocin (STZ) (control with $\mathrm{DM})$, and the third was take after 14 days treatment. Streptozotocin (STZ) is diabetogenic agent due to selective destruction of pancreatic islet $\beta$-cells. As a result of this action, the animals experience insulin deficiency, hyperglycemia, polydipsia, and polyuria, all of which are characteristic of human type 1 diabetes mellitus (8). The data were analyzed using ANOVA followed by Duncan test.

\section{RESULTS}

\section{Water content and feces consistency}

Water content and consistency of rat's feces are characteristic data in this research. The moisture content and consistency of the feces were measured on $1^{\text {st }}$ day (early intervention) and $14^{\text {th }}$ day (end of intervention). The following statistical results of moisture content and consistency of rat feces on $1^{\text {st }}$ and $14^{\text {th }}$ day. 
Table 1. Result of feses moisture level statistics test on rats $-1^{\text {st }}$ day (early intervention) and $14^{\text {th }}$ day (final intervention)

\begin{tabular}{|c|c|c|c|c|}
\hline \multirow[t]{2}{*}{ Group } & \multicolumn{2}{|c|}{ Feses Moisture Level } & \multicolumn{2}{|c|}{ Feses Consistency } \\
\hline & $1^{\text {st }}$ day & $14^{\text {th }}$ day & $1^{\text {st }}$ day & $14^{\text {th }}$ day \\
\hline Negative control & $39.40 \pm 22.09^{a}$ & $48.60 \pm 22.98^{\mathrm{a}}$ & Quite solid & Quite solid \\
\hline Positive control & $76.20 \pm 5.26^{a}$ & $75.00 \pm 47.30^{a}$ & Soft & Soft \\
\hline Comparison & $71.40 \pm 3.04^{\mathrm{a}}$ & $67.40 \pm 3.36^{a}$ & Soft & Soft \\
\hline Pure porang flour & $78.80 \pm 51.03^{a}$ & $60.60 \pm 15.97^{a}$ & Soft & Soft \\
\hline $\begin{array}{l}\text { Porang flour with } \\
\text { Strobilanthes crispa }\end{array}$ & $70.20 \pm 26.79^{a}$ & $52.60 \pm 15.01^{a}$ & Soft & Soft \\
\hline
\end{tabular}

Description : Superscript of the same letter in the same column shows no significant difference.

\section{Total cholesterol levels}

Table 2. Total serum cholesterol level before induction of Streptozotocin (STZ)

\begin{tabular}{cc} 
Group & $\begin{array}{c}\text { Total } \\
\text { Cholesterol }\end{array}$ \\
\hline Negative control & $80.44 \pm 2.50^{\mathrm{a}}$ \\
Positive control & $79.70 \pm 4.25^{\mathrm{a}}$ \\
Comparison & $81.61 \pm 3.53^{\mathrm{a}}$ \\
Pure porang flour & $77.36 \pm 5.54^{\mathrm{a}}$ \\
Porang flour with Strobilanthes & $82.49 \pm 2.23^{\mathrm{a}}$ \\
\hline
\end{tabular}

Description:The data are mean \pm Std.Deviation. Superscript of the same letter in the same column shows no significant difference.

\section{DISCUSSION}

\section{Water Content and Feces Consistency}

The content of water in rat's feces was measured to see the incidence of diarrhea in rats. Based on the result of statistical test of water content of rat's feces on $1^{\text {st }}$ and $14^{\text {th }}$ day in Table 1 and Table 2 shows that there is no significant difference of their water content in all groups. The consistency of feces on $1^{\text {st }}$ and $14^{\text {th }}$ day are the same, i.e. consistency of soft feces in Positive control, Comparison, Pure porang flour, Porang flour with Strobilanthes crispa groups. While in the Negative control group the consistency of feces is little hard.

The consistency of soft feces is caused by mixed with urine, because in groups Positive control, Comparison, Pure porang flour, and Porang flour with Strobilanthes crispa groups are a group of DM rats. Where one of the symptoms of DM is polyuria (frequent urination) (9). So that excessive urine is released and mixed with feces. While in the Negative control group the consistency of feces was little hard because the rats in the group were healthy rats. Based on observations of feces form in groups Positive control, Comparison, Pure porang flour, Porang flour with Strobilanthes crispa are oval-shaped feces, black and soft. Likewise in the Negative control group with oval, black, and little hard feces form. In general, feces with oval, black, soft, and little hard forms are included in normal feces criteria (10).

\section{Total cholesterol levels}

The average total cholesterol of rats before induction of streptozotocin (STZ) was $80.32 \mathrm{mg} /$ $\mathrm{dL}$. Where the levels exceed the normal limit of total cholesterol in rats is $10.0-54.0 \mathrm{mg} / \mathrm{dL}$. This is because in normal white mice resistant to hypercholesterolemia conditions because white rats have hyperthyroid properties. Thyroid hormone will activate the lipase-sensitive hormone so that the process of lipid catabolism in the body of the rat is high (11). Eprotirome (thyroid hormone analog) lowered serum LDL-cholesterol for dyslipidaemia, liver-selective activation of the thyroid hormone receptor (TR) although the mechanism underlying this pharmacological selectivity is incompletely understood (12)

Total cholesterol levels before and after the intervention where there are three distinct groups of total cholesterol levels i.e. group Comparison, Pure porang flour, and Porang flour with Strobilanthes crispa. The porang flour with Strobilanthes crispa group was porang flour with Strobilanthes crispa maceration intervention group, decreased total cholesterol level by $28.76 \%(p<0.05)$. This is due to the glucomannan 
Table 3. Total serum cholesterol before and after intervention

\begin{tabular}{ccccc}
\hline Group & \multicolumn{2}{c}{ Total Serum Cholesterol(mg/dl) } & p & \multicolumn{2}{c}{$\Delta \mathbf{K}$} \\
\hline Pre & $80.96 \pm 2.35$ & $84.93 \pm 3.53$ & 0.063 & $3.96^{\mathrm{a}}$ \\
Positive control & $175.80 \pm 3.20$ & $177.71 \pm 3.51$ & 0.039 & $1.91^{\mathrm{a}}$ \\
$\quad$ Comparison & $171.95 \pm 5.26$ & $113.06 \pm 2.36$ & 0.000 & $-58.89^{\mathrm{a}}$ \\
Pure porang flour & $171.54 \pm 3.28$ & $145.20 \pm 3.70$ & 0.000 & $-26.34^{\mathrm{a}}$ \\
$\quad$ Porang flour with & $175.18 \pm 2.13$ & $126.21 \pm 1.75$ & 0.000 & $-50.97^{\mathrm{a}}$ \\
Strobilanthes crispa & & & & \\
\hline
\end{tabular}

content of porang and Strobilanthes crispa maceration which is antidiabetic. Glucomannan can reduce postprandial plasma glucose rise, suppress the liver in synthesizing cholesterol, and clearing cholesterol containing bile acids (13). Strobilanthes crispa is also able to lower total blood cholesterol levels since it contains antioxidants that is flavonoids. Based on the study, flavonoids can capture free radicals and can prevent the process of lipid dosage liposomes and liposomes (14).

In the Pure porang flour group which was a group of pure flour intervention, the decreased of total blood cholesterol level was at $15.35 \%$ $(p=0.05)$. This is in line with previous research that the use of glucomannan significantly reduced total cholesterol (13). Glucomannan is a water soluble fiber. Where soluble fiber can bind fat in colons so that cholesterol can be decreased. Bile acids are generally synthesized from cholesterol. The end of bile acids in the small intestine will be taken back by the body to the liver. Fiber can bind bile acids from cholesterol in the liver causing a decrease in cholesterol levels in the liver (15).

However, porang with Strobilanthes crispa intervention can lower collesterol level than the pure porang flour intervention to the effect of decreased total cholesterol levels. Next was the glibenclamide group comparing group which decreased total cholesterol level by $34.24 \%$ after intervention $(p<0.05)$. Glibenclamide does not have a decreasing effect on total cholesterol levels. However, glibenclamide is able to optimize insulin secretion. The mechanism of glibenclamide is to stimulate the secretion of insulin from the granules of Langerhans pancreas $\beta$ cells. Its interaction with ATP-sensitive $K$ channel on the membrane $\beta$ cells can depolarize membrane and then open the $\mathrm{Ca}$ channel. Thus the $\mathrm{Ca}^{2+}$ ions will enter the $\beta$ cells then stimulate the $\beta$ cell granules and insulin secretion (16) will occur. Therefore, the produced insulin can inhibit lipolysis in adipose and muscle tissue that LDL will decrease followed by the decreased of total cholesterol levels.

\section{CONCLUSION \& RECOMMENDATION}

Based on the result of this research, it can be concluded that porang flour extract decreased the total cholesterol level of rat blood equal to $28.76 \%$. It is expected that further research on porang with Strobilanthes crispa extract mey be able to decrease total cholesterol content and identify othersubstances that most influence to the decrease of total cholesterol level.

\section{REFERENCES}

1. Dalmazi, Guido Di. Glucocorticoids and Type 2 Diabetes: From Physiology to Pathology. Journal of Nutrition and Metabolism Volume 2012, Article ID 525093, 9 pages doi:10.1155/2012/525093.

2. Zghebi, Salwa S. et al. Examining trends in type 2 diabetes incidence, prevalence and mortality in the UK between 2004 and 2014. A Journal of Pharmacology and Therapeutics. Volume19, Issue11. November 2017. Pages 1537-1545

3. Aprianti, Mahpolah Ra. Faktor-Faktor Yang Berhubungan Dengan Kadar Gula Darah Sesaat Pada Penderita Diabetes Mellitus Di Wilayah Kerja Puskesmas Gambut Kecamatan Gambut Kabupaten Banjar Tahun 2008. Al Ulum. 42, Nomor.

4. Fahri C, Sutarno, Listyawati S. Kadar Glukosa Dan Kolesterol Total Darah Tikus Putih (Rattus 
Norvegicus L) Hiperglikemik Setelah Pemberian Ekstrak Metanol Akar Meniran (Phyllanthus Niruri L). J Biofarmasi. 2005;3(1):1-6.

5. Pengembangan Ppd, Porang Indonesia. Modul Diseminasi Budidaya Dan Pengembangan Porang (Amorphophallus Muelleri Blume) Sebagai Salah Satu Potensi Bahan Baku Lokal. 2013.

6. Dharma S, Aria M, Syukri Ef. Pengaruh Ekstrak Etanol Daun Kejibeling (Strobilanthes Crispa (L) Blume) Terhadap Kelarutan Kalsium Dan Oksalat Sebagai Komponen Batu Ginjal Pada Urin Tikus Putih Jantan. Scientia. 2014;4(1):347.

7. Astuti, R.D., Agus P, and Veriani A. Porang flour (Amorphophallus oncophyllus) with and without soaking of keji beling extract increases the value of ureum on toxicity test in wistar rat (Rattus norvegicus). Jurnal Gizi dan Dietetik Indonesia (Indonesian Journal of Nutrition and Dietetics) 5.3. 2018: 93-97.

8. Furman, B.L. 2015. Streptozotocin-induced diabetic models in mice and rats. Curr. Protoc. Pharmacol. 70:5.47.1-5.47.20.doi: 10.1002/0471141755.ph0547s70

9. Chandra F, Restuastuti Bagian IImu Kesehatan Masyarakat Kedokteran Komunitas Fakultas Kedokteran Universitas Riau T. Faktor-Faktor Risiko Pasien Diabetes Melitus. Ber Kedokt Masy. 2007;23(3):142-7.
10. Hartanti A. Evaluasi Aktivitas Antidiare Isolat Lactobacillus Dari Air Susu Ibu. Institut Pertanian Bogor; 2010.

11. Murray, R.K., Granner, D.K., Mayes, P.A., Rodwell Vw. Biokimia Harper. 25th Ed. Jakarta: Penerbit Buku Kedokteran Egc.; 2003.

12. B. Angelin et al. Reductions in serum levels of LDL cholesterol, apolipoprotein B, triglycerides and lipoprotein(a) in hypercholesterolaemic patients treated with the liverselective thyroid hormone receptor agonist eprotirome. Journal of Internal Medicine, 2015, 277; 331-342

13. Sood N, Baker WI, Coleman Ci. Effect Of Glucomannan On Plasma Lipid And Glucose Concentrations, Body Weight, And Blood Pressure: Systematic Review And Meta- Analysis. Am J Clin Nutr [Internet]. 2008;88(4):1167-75. Available From:Http:// Www.Ncbi.Nlm.Nih.Go v/Pubmed/18842808

14. Peng I-W, Kuo S-M. Flavonoid Structure Affects The Inhibition Of Lipid Peroxidation In Caco-2 Intestinal Cells At Physiological Concentrations.J Nutr. 2003;133(7):2184-7.

15. Martati E, Lestari A. The Effect Of Chitosan On Lipid Profile Of Sprague Dawley Rat Blood Serum. Teknol Pertan. 2008;9(3):157-64.

16. Mythili Md, Vyas R, Akila G Gs. Effect Of Streptozotocin On The Ultrastructure Of Rat Pancreatic Islets. Microsc Res Tech. 2004;63(5):274-81. 